\title{
THE MAKING OF THE BIOGRAPHICAL DICTIONARY OF MODERN BRITISH RADICALS
}

\author{
BY NORBERT J. GOSSMAN \\ Professor Gossman teaches history at the University of Detroit
}

B ACK in the I 960's when student radicals were grabbing the headlines with sieges at Columbia and Berkeley, I was involved in a research project on nineteenth-century British radicalism. In attempting to track down little-known working class journalists and republicans of the Chartist era, I found the standard reference works clearly inadequate. The Dictionary of National Biography did not include many of them, nor was there for British history a reference work similar to the French Dictionnaire Biographique du Mouvement Owvrier Français.

After publishing articles on English republicanism and the relationship of British radicals to the Continental revolutionaries, I decided to follow up on the idea of a biographical dictionary of British radicals. Jean Hecht of Columbia was one of the first to give encouragement. He was teaching at the University of Michigan in Ann Arbor one summer and was kind enough to invite me to lunch. From that initial discussion came plans for an annual Michigan British historian's luncheon and further correspondence in which I presented my idea for a dictionary of British radicals. The next and most important step was contact with Joe Baylen of Georgia State, who had similar research interests and valuable contacts with British historians here and in England.

One of the first problems that we had was reaching an agreement on definition. Everyone had their own idea of the meaning of radicalism. Should radicalism be seen in a Marxist context or as a middle-class nonconformist phenomenon? Was radicalism a question of policy, ideology or temperament? Was a radical, to quote one nineteenth-century writer, "every man that shuts his mouth to keep out flies"? What followed here and in all our work on this project was extensive correspondence with as many historians as possible and finally a consensus.

British radicalism, we decided, was a many-faceted and ever-changing aspect of modern British politics and society. Radical was interpreted to include those persons whose programs and work involved something 
more than a moderate adjustment of policy or minor change in the operation of political, social and economic institutions. We decided to include in the dictionary the major and minor figures in the labor movement, parliamentary reform, Chartism, socialism, republicanism, feminism, positivism, disestablishment, temperance and imperial reform. In part the dispute over meaning centers on the period under discussion. Radicalism at the close of the nineteenth century is clearly much different than radicalism at the end of the eighteenth century. Free trade was a radical cause in I 800 but not in I 900 ; women's suffrage was a radical issue in 1900 but not in 1970 .

Many problems remained before the dictionary would become a reality. Contributors were needed to write the entries, and we had to secure a publisher. The first contributor list was made up of friends and colleagues in the field that were known to us, but to complete the hundreds of entries more contributors were needed. These additional contributors came to us by recommendation from senior historians in the area of modern British history, in answer to our advertising in such journals as the British Studies Monitor, the British Studies Mercury, British Studies Intelligencer and the $A H A$ Newsletter, and by a careful reviewing of the topics of new doctoral dissertations. Form letters were never used to contact anyone. A personal letter was always sent to a prospective contributor.

The project moved very slowly. Patience and prudence were the watchwords. One of those who was especially important in the early months of the planning was Joseph Kelly, who was teaching history at the time but is now a lawyer in Racine, Wisconsin. He and his family spent the summers of 1971 and 1972 in England, and Joe managed to meet almost everyone at Oxford and in London and Newcastle-uponTyne who were in any way interested in the area of British radicalism. Many of our English and Scottish contributors came from Joe's contacts.

Lists of contributors were paralleled by lists of radicals. Who should be included? With the rather broad definition of radicalism agreed to, the lists rapidly expanded. Contributors were asked to nominate radicals. Advisory editors reviewed the lists and made suggestions. We were especially concerned about including representatives from all groupsEnglish Jacobins to World War I Pacifists. The lists remained openended and periodically revised. These lists were sent to prospective contributors.

Where to begin the dictionary was another question. We had to be 
concerned with origins. When did modern British radicalism have its beginning? Several opinions had been expressed on this point but we decided that the best place to begin was the eighteenth century and, more specifically, the decade of the I 770 's. True, there had been important radical activity in the era of the Civil War and the Cromwellian Republic, but the firtation with republicanism and democracy was shortlived. The Anglican church, king, and aristocracy were restored. The century after the Restoration did not witness a series of victories for the radical cause. Many ideas and events came together in the 1770 's to bring radicalism to the center of the stage for the first time in a century. To many Whigs the power of the Crown in the person of George III was a threat to liberty. To the Whigs and others, the American Revolution and the English defeat in the American War of Independence revealed the corruption of the old society. The intellectual conditioning had been provided by the Enlightenment. Bentham's first significant publication was in the I 770 's, and his arguments owe much to the thought of the French philosophes. The English constitution and society did not seem to meet the rational and/or scientific test and did not appear to be in the natural order of things. It was at this point in England as well as in France that the demand for wholesale change began. Twenty years later the tempo of British radicalism increased with the enormous impact and stimulation of the French Revolution.

Securing a publisher was also a challenge. In 1972 Greenwood displayed considerable interest in the project but wanted to change the format of the dictionary by making the shorter unsigned entries correspond with the format of their other reference works. This was unacceptable to us. Shortly after this Joe Baylen, who was on a Fulbright in England, 1972-1973, negotiated a contract with the Harvester Press, and our original format of the longer signed biographies was sustained.

By this time we had a serious publishing rival, the Dictionary of Labour Biography (MacMillan), edited by Joyce Bellamy and John Saville of the University of Hull. The D.L.B. had been in the planning stages since 1960, following the death of G.D.H. Cole. There was concern in both camps about duplication. Correspondence with Margaret Cole and John Saville established a friendly relationship. The D.L.B. emphasis is on the labor movement including the rank and file members but ignores middle class radicals (Bright and Cobden e.g.) who had no definite connection with the labor movement. Our emphasis was to be on radical movements-labor and others, working class and middle class. 
The D.L.B. volumes are organized around certain industries; volume I, for example, encompasses miners and cooperators, and is not as concerned with chronology. The Biographical Dictionary of Modern British Radicals, by contrast, was to be a more traditional chronological survey of all radicals. The first volume covered the years I770-I 830. From the beginning we agreed to cross-reference duplicate entries with the D.L.B.

Six years passed from the time of securing a publisher (1973) to the appearance of the first volume ( 1979). There were many pitfalls along the way. Fictitious entries, for example, were always a possibility. Obscure radicals could indeed be non-existent-as were some of the "saints" in the early church. We were pressed by some contributors who insisted that their favorite radical merited 10,000 words and not the mere 3,000 which we had established as a maximum. Deadlines were a major problem. Volume I was held up for six months by the repeated promise but continued failure of one contributor to send along a biography. A labor dispute in England held up the printing, which resulted in sending the manuscript to India where the printing was completed. Unfortunately the Indian printers did a less than professional job and some of the entries are marred by misprints.

There have been rewards too. The dictionary has afforded me the opportunity to meet, via correspondence and sometimes personally, many historians I would otherwise have never known. It has widened my own knowledge of radicalism and provided me with updated bibliographies on radicals in every area. Consequently the experience has served to enrich my seminars and advanced courses in English history, including a course entitled "Modern British Radicalism" which I started teaching in $197 \mathrm{I}$.

It is my hope that the Biographical Dictionary of Modern British Radicals will serve as a useful volume for students in the area of modern British history. The dictionary's strength lies in the number of first-rate scholars who freely contributed biographies to it. My own contribution was the introductory article exploring the origin and meaning of modern British radicalism in the period $1770-1830$. Here my debt to many of my contributor correspondents is obvious and duly footnoted. 